\title{
Glaucoma: A Gist of Visual Impairment
}

\author{
Kumar $\mathrm{A}^{1 *}$, Ranjan $\mathrm{A}^{2}$, Yadav $\mathrm{S}^{2}$, Vishwakarma $\mathrm{P}^{1}$ and Agarwal $\mathrm{S}^{1}$ \\ ${ }^{1}$ Department of Medical Genetics, Sanjay Gandhi Post Graduate Institute of Medical Sciences, India \\ ${ }^{2}$ Department of Anatomy, Hind Institute of Medical Sciences, India
}

Submission: September 13, 2017; Published: September 25, 2017

*Corresponding author: Kumar A, Department of Medical Genetics, Sanjay Gandhi Post Graduate Institute of Medical Sciences (SGPGIMS), India, Tel: 91- 522-2494356/49, +91-8840078782; Fax: 91-522-2668017; E-mail: chemistry.ashok83@gmail.com

\begin{abstract}
Glaucoma forms worldwide basis for visual impairment and sightlessness. Every single type of glaucoma produces damage to optic nerve neurons and is most frequently linked with raised level of intraocular pressure. Intraocular pressure mounts up mainly due to inadequate outflow of aqueous humour and its continuous production via ciliary body. A positive family history serves as chief risk factor for the disease. Diagnosis of the disease at premature stage and periodic therapeutic follow ups helps to slow down its developmental rate. Though research has been going on to develop a Neuro-protective drug or surgical technique to absolutely prevent the disease progression but success has not been achieved yet.
\end{abstract}

Keywords: Glaucoma; IOP (Intraocular pressure); Trabecular meshwork (TBM); Genetics; Pathogenesis; Diagnosis; Therapeutics

\section{Introduction}

Glaucoma is emerging as a major irretrievable visual impairment in past few years. Success has not been achieved yet to recover the vision loss produced by glaucoma [1]. Presently, nearly sixty seven million populations are suffering from glaucoma across the world [2]. Highlighting point revealed through various studies is that only a smaller number of people are aware about the disease amongst the affected ones [3]. The reason of unawareness is asymptomatic nature of glaucoma till the very late stage. This renders it unidentifiable at early stage so the disease progresses and the treatment get delayed.

Exact theory leading to glaucoma is not very clear [4] but by so far studies have succeeded in figuring out certain risk factors associated with the disease. High intraocular pressure (IOP), increased cup disk ratio, asymmetrical cup-disk ratio, disc haemorrhage is some of the common factors behind it [5]. Other factors include positive family history, obesity, migraine and high blood pressure [1]. The term glaucoma includes an assembly of optic disorders that lead to optic nerve death. This is characterized by cupping of optic disc $[1,6]$. There are several types of glaucoma, out of which open angle glaucoma is most frequently observed. It is painless and progresses slowly. Loss of visual field occurs from periphery to centre leading to total blindness [6]. Other less common type is closed angle glaucoma. Its rate of progression varies. A sudden onset is usually accompanied by pain, dilated pupil and blurring of vision [1-6].
The best way to overcome glaucoma is consciousness of its risk factors so that treatment could be initiated. Individuals with a family history and abnormal optic findings should go for entire ophthalmologic examination. Most common risk factor is elevated intraocular pressure; therefore reduction of pressure turns out to be a good option. Also, there are various other options to slow down the rate of progression such as hypotensive eye drops, trabeculoplasty and surgery. Prognosis of the disease can be improved by sincerely following the prescribed medications and cyclic follow up [7].

\section{Genetic view of the disease}

Studies reveal that having a positive family record of the disease increases the risk of glaucoma manifolds. Specific genes are associated with every type of glaucoma which makes it easier to distinguish each one genetically. Primary open angle glaucoma has been linked with a number of genes, namely MYOC, WDR36, TBK1, ASB10 and NTF4 [8]. First gene found to be associated with primary open angle glaucoma was MYOC, encoding for myocilin protein [9]. Familial normal tension glaucoma, which is a variety of primary open angle glaucoma, is found to be related with OPA1 and OPTN genes [10] (Table 1). One interesting finding shows, the people having mutation in OPTN gene express normal level of intraocular pressure than those with MYOC gene [11]. A recent study using patients with primary angle closure glaucoma and controls from different asian populations identified significant 


\section{Global Journal of Intellectual \& Developmental Disabilities}

associations with the PLEKHA7 and COL11A1 genes and an intergenic region between PCMTD1 and ST18 on chromosome 8q16. It is not yet known how these genes may contribute to PACG, although potential mechanisms include the regulation of cellular permeability, scleral rigidity and ocular growth [12]. This clearly depicts that open angle and closed angle glaucoma are genetically distinct from each other. CYP1B1 coding for cytochrome P450 1B1 and LTBP2 (latent transforming growth factors binding protein) is associated with congenital glaucoma (Table 1). Mutations in both genes cause autosomal recessive congenital glaucoma [13]. The role/s of the mutant proteins in disease pathogenesis is not yet known.

Table 1: Glaucoma Genetics.

\begin{tabular}{|c|c|c|c|}
\hline $\begin{array}{c}\text { Chromosome } \\
\text { locus }\end{array}$ & Condition & Locus & $\begin{array}{c}\text { Inheritance } \\
\text { pattern }\end{array}$ \\
\hline $7 \mathrm{q} 35$ & Adult onset POAG & GLC1F & $\mathrm{AD}$ \\
\hline $15 q 11-q 13$ & Adult-onset POAG & GLC1I & Complex \\
\hline 10p15-p14 & Adult onset POAG & $\begin{array}{l}\text { GLC1E } \\
\text { (OPTN) }\end{array}$ & $\mathrm{AD}$ \\
\hline $11 \mathrm{q} 12$ & Nanophthalmos & VMD2 & $\mathrm{AD}$ \\
\hline $4 q 25$ & Rieger Syndrome & $\begin{array}{l}\text { RIEG1 } \\
\text { (PITX2) }\end{array}$ & $\mathrm{AD}$ \\
\hline $5 q 22$ & POAG & WDR36 & complex \\
\hline $20 \mathrm{p} 12$ & Early Onset POAG & GLC1K & $\mathrm{AD}$ \\
\hline $5 q 22$ & Adult onset POAG & GLC1G & $\begin{array}{c}\text { AD, } \\
\text { COMPLEX }\end{array}$ \\
\hline $11 \mathrm{p} 13$ & Aniridia & AN2(PAX6) & $\mathrm{AD}$ \\
\hline $1 \mathrm{p} 36$ & Congenital glaucoma & GLC3B & $\mathrm{AR}$ \\
\hline 2 cen-2q13 & Adult onset POAG & GLC1B & $\mathrm{AD}$ \\
\hline $3 q 21-24$ & Adult onset POAG & GLC1C & $\mathrm{AD}$ \\
\hline $6 \mathrm{p} 25$ & Iridodysgenesis & $\begin{array}{l}\text { IRID1 } \\
\text { (FOXC1) }\end{array}$ & $\mathrm{AD}$ \\
\hline $7 q 35-q 36$ & $\begin{array}{l}\text { Pigment dispersion } \\
\text { syndrome }\end{array}$ & GPDS1 & $\mathrm{AD}$ \\
\hline $8 q 23$ & Adult onset POAG & GLC1D & $\mathrm{AD}$ \\
\hline $9 q 22$ & Early onset POAG & GLC1J & $\mathrm{AD}$ \\
\hline $9 q 34$ & $\begin{array}{l}\text { Glaucoma associated } \\
\text { with nail patella } \\
\text { syndrome }\end{array}$ & (LMX1B) & $\mathrm{AD}$ \\
\hline $11 p$ & Nanophthalmos & NNO1 & $\mathrm{AD}$ \\
\hline $1 \mathrm{q} 23$ & $\begin{array}{c}\text { Early and adult onset } \\
\text { POAG }\end{array}$ & GLC1A & $\begin{array}{c}\text { Early- } \\
\text { onset AD } \\
\text { Adult-onset, } \\
\text { complex }\end{array}$ \\
\hline $11 \mathrm{q} 23$ & Nanophthalmos & MFRP & $\mathrm{AR}$ \\
\hline $13 q 14$ & RiegerSndrome & RIEG2 & $\mathrm{AD}$ \\
\hline $14 \mathrm{q} 11$ & Adult -onset POAG & $\begin{array}{l}\text { Locus } \\
\text { Pending }\end{array}$ & Complex \\
\hline $15 q 24$ & Late onset & LOXL1 & complex \\
\hline $16 q 23.2$ & Congenital glaucoma & MAF & Complex \\
\hline $12 \mathrm{q} 14$ & POAG & TBK1 & Complex \\
\hline $11 p$ & Nanophthalmos & NNO2 & $\mathrm{AD}$ \\
\hline $2 \mathrm{p} 21$ & Congenital glaucoma & $\begin{array}{c}\text { GLC3A } \\
\text { (CYP1B1) }\end{array}$ & $\mathrm{AD}$ \\
\hline
\end{tabular}
enters pupil. Through pupil it makes an entry into anterior chamber (area between iris and cornea). Anterior chamber is actually the angle between iris and cornea. After filling this irido-corneal angle, aqueous humor flows through trabecular meshwork and makes an exit from eye by draining through collector channels into schlemm's canal. It then flows into scleral plexus and finally returns to general circulation [14]. Any disturbance in this pathway leads to fluctuation in intraocular pressure level. Elevated intraocular pressure causes mechanical deformation of lamina cribrosa which is the exit point for axons of ganglion cells of retina (axons of which form optic nerve). This damages the ganglion cells and hence the optic nerve [15].

In open angle glaucoma, trabecular meshwork is blocked either due to degeneration or because of clogging. This reduces the absorptive capacity of trabecular meshwork. On the other hand ciliary process continues to produce aqueous humor. This leads to accumulation of aqueous humor. Aqueous humor now forces its way through clogged trabecular meshwork. This increased resistance in aqueous outflow builds up pressure over time, resulting in degeneration of retinal ganglion cells. All these events gradually lead to death of optic nerve and finally complete loss of vision [16]. While as, in case of angle closure/ acute glaucoma, iris and cornea get pressed against each other leading to disappearance of iridocorneal angle. Abrupt closure of this angle obstructs the access of aqueous humor flow into anterior chamber and its drainage through trabecular meshwork. This causes rapid accumulation of aqueous humor in posterior chamber, thereby producing brisk rise in intraocular pressure. Acute rise in level of intraocular pressure deteriorates retinal ganglion cells leading to optic nerve death and total blindness within few hours. That is why it has been declared as an emergency condition. Sudden increase in ocular pressure presents as severe pain, redness in eye, nausea and headache $[1,2]$.

\section{Diagnosis}

Regardless of having a steady relationship with glaucoma, intraocular pressure cannot be considered as much reliable factor while making diagnosis of the disease. Many findings suggest that significant number of individuals having raised ocular pressure, do not end up with glaucoma even after prolonged follow up 
[1]. Analysis of the disease at premature stage can improve the prognosis. Here, primary healthcare physicians can play an important role by referring the individuals to ophthalmologist, who are likely to develop glaucoma. This category includes those who have positive family history of the disease. Primary physicians may also go for optic nerve examination through ophthalmoscope in suspected cases and advising positive ones to go for complete ophthalmologic examination [5]. Although, standard eye examination performed by ophthalmologists includes screening for glaucoma, diagnosis at premature stage is quite difficult. Because almost $50 \%$ of retinal ganglion cells have already been lost by the time characteristic changes appear in standard visual field testing. Also, signs and symptoms appear only after severe loss of optic nerve fibres. Therefore a complete ophthalmologic examination turns out to be a useful tool as no single criteria can be taken as standard point in determination Table 2: Diagnosis of Glaucoma.

\begin{tabular}{|c|c|c|}
\hline Test Name & Test explains about & Inference \\
\hline Tonometry & Inner eye pressure & $\begin{array}{l}\text { Firstly eyes numbed by eye drops and then examiner use tonometer for check inner } \\
\text { pressure of eye via pressure applied by the puff of warm air or a tiny tool }\end{array}$ \\
\hline Ophthalmoscopy & $\begin{array}{l}\text { Dilated eye examination } \\
\text { and also shape and color of } \\
\text { the optic nerve }\end{array}$ & $\begin{array}{l}\text { Firstly the pupil is dilated via the application of eye drops then Use a small } \\
\text { magnification device with a light on the end, by which can examine the magnified } \\
\text { optic nerve }\end{array}$ \\
\hline $\begin{array}{l}\text { Perimetry or Visual field } \\
\text { test }\end{array}$ & Complete field of vision & $\begin{array}{l}\text { Patient look straight ahead then is asked to indicate when light passes the patient's } \\
\text { peripheral field of vision. This can examine to map the patient's field of vision. }\end{array}$ \\
\hline Gonioscopy & $\begin{array}{l}\text { Examine Angle where the } \\
\text { iris meets the cornea in } \\
\text { eye }\end{array}$ & $\begin{array}{l}\text { Firslt numb the eye via eye drops, then A hand-held contact lens with a mirror is } \\
\text { placed gently on eye to allow the examiner to see the angle between the cornea and } \\
\text { the iris }\end{array}$ \\
\hline Nerve fibre analysis & $\begin{array}{l}\text { Examine the nerve fiber } \\
\text { layer Thickness }\end{array}$ & By the Use one of several techniques, the nerve fibers are examined. \\
\hline Pupil Dilation & Examine the inside of eye & $\begin{array}{l}\text { Special eye drops temporarily enlarge the pupil so that the doctor can better view } \\
\text { inside of the eye. }\end{array}$ \\
\hline Pachymetry & $\begin{array}{l}\text { Examine thickness of } \\
\text { cornea }\end{array}$ & Examiner places a pachymeter on the front of the eye to measure thickness of Cornea \\
\hline
\end{tabular}

Open angle glaucoma is usually asymptomatic till the significant amount of optic nerve fibre loss occurs. Vision loss progresses centripetally from periphery towards centre. Characteristic feature called as 'cupping' of optic nerve is seen in this type. While in case of angle closure glaucoma, gonioscopy is the routinely performed technique to examine the iridocorneal angle (Table 2). Still gonioscopic findings are not much reliable as they get altered by intensity of light or mechanical compression during inspection. To overcome this difficulty a non contact imaging technique called anterior segment optical coherence tomography has been installed. Comparative studies reveal better diagnosis than gonioscopy [20]. Ultrasound biomicroscopy, is an imaging technique which produces high resolution images $(25 \mu \mathrm{m}-50 \mu \mathrm{m})$ of iridocorneal angle (Table 2$)$. It also allows visualisation of ciliary process, lens zonules and choroid to figure out the etiology [21]. Also symptoms like mild dilated pupil, unresponsive to light, oedematous cornea, redness and pain in eye can be the identification factors. But physical signs appear only when disease has already been advanced. of the disease. Any damage to neurons of optic nerve produces characteristic changes which forms essential feature during identification of glaucoma through ophthalmoscopic examination of optic nerve head [17] (Table 2). Longitudinal evaluation of optic nerve head through ophthalmoscope might reveal any damage in the structure [18]. Quantitative loss of retinal ganglion cells with time can be detected through laser scanning imaging techniques which include cofocal ophthalmoscopy, polarimetry and optical coherence tomography [19]. Other factors to be observed are intraocular pressure, irido corneal angle, optic cup to disc ratio and rim appearance. Central corneal thickness can result in variations in level of intraocular pressure. More than normal corneal thickness may produce raised intraocular pressure and vice versa. So as to reduce the error in pressure measurement, pachymetry should be performed along to nometry.

\section{Therapeutics and management}

Foremost aim of treatment of glaucoma is to improve the life of patients by reducing the progression rate of disease [22]. Constant counselling of patient about importance of falling in line with treatment regimen can greatly enhance the success of treatment plan. Since raised intraocular pressure remains the most frequent finding of glaucoma, prime objective of most of the treatment schedule is to reduce it [23]. Various studies support the fact that by lowering intraocular pressure, progression of glaucoma slows substantially [24]. Also, those who had elevated intraocular pressure did not developed glaucoma when went through a long term follow up [25]. American academy of ophthalmology has proposed a new mode to reduce intraocular pressure. In this method a target value of intraocular pressure is set on the basis of previous treatment pressure levels which produced optic nerve damage, extent of damage, factors associated with disease progression and life expectancy. Aim is to achieve the target pressure level through selective and effective 
medications with minimal side effects. Continuous monitoring of pressure and modifying treatment plan accordingly, improves the efficacy of method [26].

\section{Medications}

Drugs available for glaucoma now a day, mainly lower the intraocular pressure in one or the other way. Prostaglandin analogue is the drug of choice as it produces no major systemic adverse effects. Conjuctival hyperaemias, loss of orbital fat, periocular skin pigmentation are some of the local side effects produced by it. It improves aqueous outflow via uveoscleral pathway and hence reduces the ocular pressure. It is administered once in night [27]. Other medicines are opted only in case of intolerance to prostaglandin analogues because prostaglandin analogues have been proved more effective than Table 3: Therapeutics for Glaucoma. other drugs [28] (Table 3). $\beta$-blockers are contraindicated in COPD (chronic obstructive pulmonary disease) and asthma patients as they generate life threatening systemic adverse effects [29]. $\beta$-adrenergic blockers decrease intraocular pressure by reducing the production of aqueous humor from ciliary body (Table 3). Alpha-2 adrenergic agonists reduce aqueous humor production and simultaneously increase its drainage. Parasympathomimetics reduce the resistance in aqueous humor outflow through trabecular meshwork. Carbonic anhydrase inhibitors diminish the aqueous humor production [30]. Prostaglandin analogues and carbonic anhydrase inhibitors are effective during day as well as in night. $\beta$-adrenergic blockers and $\alpha$-adrenergic agonists reduce eye pressure only during day [31] (Table 3).

\begin{tabular}{|c|c|c|c|c|}
\hline \multicolumn{4}{|c|}{ Medical Treatment: Drugs That Increase Aqueous Outflow } & \multirow[b]{2}{*}{ Side Effects } \\
\hline S.N. & & Mechanism & Administration & \\
\hline 1 & $\begin{array}{l}\text { Nonspecific Adrenergic } \\
\text { Agonists [epinephrine, } \\
\text { dipivefrin] }\end{array}$ & $\begin{array}{l}\text { 个uveoscleral outflow of } \\
\text { aqueous humor }\end{array}$ & Topical drops & $\begin{array}{l}\text { Can precipitate acute attack in patients } \\
\text { with narrow iris-corneal angle, headaches, } \\
\text { cardiovascular arrhythmia, tachycardia }\end{array}$ \\
\hline 2 & $\begin{array}{l}\text { Parasympathomimetics } \\
\text { [pilocarpine, carbachol, } \\
\text { echothiophate] }\end{array}$ & $\begin{array}{l}\uparrow \text { contractile force of } \\
\text { ciliary body muscle, } \\
\uparrow \text { outflow via TM }\end{array}$ & $\begin{array}{l}\text { Topical drops or gel, } \\
\text { (slow-release plastic } \\
\text { insert) }\end{array}$ & $\begin{array}{l}\text { Headache, induced myopia. Few systemic SE } \\
\text { for direct-acting agonists vs. AchE inhibitors } \\
\text { (diarrhea, cramps, prolonged paralysis in setting of } \\
\text { succinylcholine). }\end{array}$ \\
\hline 3 & $\begin{array}{l}\text { Prostaglandins } \\
\text { [latanoprost] }\end{array}$ & $\begin{array}{l}\text { May } \uparrow \text { uveoscleral outflow } \\
\text { by relaxing ciliary body } \\
\text { muscle }\end{array}$ & Topical drops & Iris color change \\
\hline \multicolumn{5}{|c|}{ Medical Treatment: Drugs That Decrease Aqueous Production } \\
\hline & $\begin{array}{l}\text { Beta-Blockers } \\
\text { [levobunolol, timolol, } \\
\text { carteolol, betaxolol] }\end{array}$ & $\begin{array}{l}\text { Act on ciliary body to } \downarrow \\
\text { production of aqueous } \\
\text { humor }\end{array}$ & $\begin{array}{l}\text { Topical drops to avoid } \\
\text { systemic effects }\end{array}$ & $\begin{array}{l}\text { Cardiovascular (bradycardia, asystole, syncope), } \\
\text { bronchoconstriction (avoid with b1-selective } \\
\text { betaxolol), depression }\end{array}$ \\
\hline 2 & $\begin{array}{l}\text { Alpha-2 Adrenergic } \\
\text { Agonists [apraclonidine, } \\
\text { brimonidine] }\end{array}$ & $\begin{array}{l}\downarrow \text { production of aqueous } \\
\text { humor }\end{array}$ & Topical drops & $\begin{array}{l}\text { Lethargy, fatigue, dry mouth [apraclonidine is a } \\
\text { derivative of clonidine (antihypertensive) which } \\
\text { cannot cross BBB to cause systemic hypotension] }\end{array}$ \\
\hline 3 & $\begin{array}{l}\text { Carbonic Anhydrase } \\
\text { Inhibitors [acetazolamide, } \\
\text { dorzolamide] }\end{array}$ & $\begin{array}{l}\text { Blocks CAII enzyme } \\
\text { production of bicarbonate } \\
\text { ions (transported to } \\
\text { posterior chamber, } \\
\text { carrying osmotic water } \\
\text { flow), thus } \downarrow \text { production } \\
\text { of aqueous humor }\end{array}$ & Oral, topical & $\begin{array}{c}\text { malaise, kidney stones, possible (rare) aplastic } \\
\text { anemia }\end{array}$ \\
\hline
\end{tabular}

\section{Surgery}

Surgical management is indicated in case of severe advancement of disease and when satisfactory results are not achieved through medicinal therapy. Various surgical techniques are available these days offering good prognosis. Laser trabeculoplasty aims at lowering intraocular pressure by modulating the trabecular meshwork and thereby improving aqueous humor drainage through it. In argon laser trabeculoplasty (ALT), a thermal argon laser beam is used to bring alterations in trabecular meshwork. This leads to opening of meshwork and thus reducing the resistance in aqueous outflow. Recent technique uses cold argon laser beam and is known as selective laser trabeculoplasty (SLT). Both techniques are equally effective but loose efficiency with time. SLT can be repeated three or four times while as ALT can only be used once [32]. Another procedure called trabeculectomy is most frequently performed surgical technique to treat open angle glaucoma. A partial thickness sclera flap is raised and small section of trabecular meshwork is excised to release the ocular pressure. Flap is then loosely sutured to allow the fluid drainage. Fibro proliferative response is usually seen after surgery leading to scarring and thereby reducing the success rate of surgery. To overcome this dilemma, chemotherapeutic adjutants are applied which inhibit fibroblast proliferation. Non chemotherapeutic agents such as collagen matrix have proved useful by hampering the contraction and adhesion of wound mechanically [33,34]. All other techniques are less effective than trabeculectomy in relieving intraocular pressure but as it is associated with high risk of complications, other methods are opted [35]. 
Canaloplasty is a technique in which an incision is made to approach canal of schlemm. A micro catheter is passed through it to enlarge the draining channel which lowers the intraocular pressure [36]. Nonpenetrating deep sclerotomy slightly differs from trabeculoplasty. Here, a second deep sleral flap is raised and schlemm's canal is deroofed to release the pressure. Studies reveal that it exhibits fewer complications than trabeculoplasty since it is performed with biocompatible devices such as collagen matrix, implants [37]. Several types of glaucoma drainage implants are available now days which are used in adjunct with surgical procedures to lessen the postoperative side effects [38]. Iridotomy is another useful and regularly performed surgical technique to treat angle closure glaucoma. In this procedure, iris is punctured through full thickness which evens out the pressure on either side of it. Technique demands episodic follow ups as pressure rebuilds over time. Post surgical side effects are rare but include sudden rise of intraocular pressure, posterior synechiae formation [39].

\section{Conclusion and Future Prospective}

New treatments are developed in order to improve the prognosis of therapeutics through translational research. Term translational research involves development of new diagnostic tests, drugs and intervention techniques for patients with an established understanding of their disease development and progression. The main goal of translational research is to integrate advances in clinical trials and research from the bench to the bedside. Translational research also enables faster development of potential therapies reducing the time between the identification of drug targets and the availability of clinically relevant treatment options. Ongoing translational research involves rho kinase inhibitors. Rho kinase inhibitors (as ripasudil) work by inhibition of the actin cytoskeleton, resulting in the morphological changes in the trabecular meshwork (TM) and increased aqueous outflow (compounds in phase 2 and phase 3 trials). Stem cell is the area of constant interest of researchers and scientists. Delivery of stem cell derived neurotrophic factors slows down retinal ganglion cell loss in glaucoma models and optic nerve and optic tract trauma.

Several neuroprotective agents are under research and investigation. A 2013 Cochrane Systematic Review compared the effect of brimonidine and timolol in slowing the progression of open angle glaucoma in adult participants. The results showed that participants assigned to brimonidine showed less visual field progression that those assigned to timolol (though the results were not significant). Participants in the brimonidine group had a higher occurrence of side effects caused by medication than participants in the timolol group. Alternative medications with better results and fewer complications are being developed. Natural compounds of research interest in glaucoma prevention or treatment include: fish oil and omega 3 fatty acids, alpha lipoic acid, bilberries, vitamin E, cannabinoids, carnitine, coenzyme Q10, curcurmin, Salvia miltiorrhiza, dark chocolate, erythropoietin, folic acid, Ginkgo biloba, ginseng, L-glutathione, grape seed extract, green tea, magnesium, melatonin, methylcobalamin, N-acetyl-L cysteine, pycnogenols, resveratrol, quercetin and salt. However, most of these compounds have not demonstrated effectiveness in clinical trials. In an effort to determine whether marijuana or drugs derived from it, might be effective as a glaucoma treatment, the US National Eye Institute supported research studies from 1978 to 1984. These studies demonstrated some derivatives of marijuana lowered IOP when administered orally, intravenously, or by smoking, but not when topically applied to the eye.

In 2003, the American Academy of Ophthalmology stating that cannabis was not more effective than prescription medications. Furthermore, no scientific evidence has been found that demonstrates increased benefits and/or diminished risks of cannabis use to treat glaucoma compared with the wide variety of pharmaceutical agents now available. In 2012, the American Glaucoma Society stated that the use of cannabis as a legitimate treatment for elevated IOP, for reasons including short duration of action and side effects that limit many activities of daily living.

\section{Acknowledgement}

Ashok Kumar is thankful to DST-New Delhi [DSTNPDF/2015/000951] for providing fellowship and indebt to Sanjay Gandhi Post Graduate institute of Medical Sciences (SGPGIMS), Lucknow for providing infrastructure facility. No funding was available for publishing the manuscript.

\section{References}

1. (2016) Facts about Glaucoma. National Eye Institute, USA.

2. Mantravadi AV, Vadhar N (2015) Glaucoma. Primary care 42(3): 43749.

3. Budenz DL, Barton K, Whiteside-de Vos J (2013) Prevalence of glaucoma in an urban West African population: the Tema Eye Survey. JAMA Ophthalmol 131(5): 651-658.

4. Nickells RW, Howell GR, Soto I, John SW (2012) Under pressure: cellular and molecular responses during glaucoma, a common neurodegeneration with axonopathy. Annu Rev Neurosci 35: 153-179.

5. Hollands H, Johnson D, Hollands S, Simel DL, Jinapriya D, et al. (2013) Do findings on routine examination identify patients at risk for primary open-angle glaucoma? JAMA 309(19): 2035-2042.

6. Weinreb RN, Khaw PT (2004) Primary open-angle glaucoma. Lancet 363(9422): 1711-1720.

7. Weinreb RN, Aung T, Medeiros FA (2014) The Pathophysiology and Treatment of Glaucoma A Review. JAMA 311(18): 1901-1911.

8. (OMIM) Glaucoma, Primary Open Angle; POAG 137760.

9. Kwon YH, Fingert JH, Kuehn MH, Alward WL (2009) Primary openangle glaucoma. N Engl J Med 360(11): 1113-1124.

10. (OMIM) Glaucoma, Normal Tension, Susceptibility To 606657

11. Rezaie T, Child A, Hitchings R (2002) Adult-onset primary open-angle glaucoma caused by mutations in optineurin. Science 295(5557): 10771079.

12. Vithana EN, Khor CC, Qiao C (2012) Genome-wide association analyses identify three new susceptibility loci for primary angle closure glaucoma. Nat Genet 44(10): 1142-1146. 
13. Stoilov I, Akarsu AN, Alozie I (1998) Sequence analysis and homology modeling suggest that primary congenital glaucoma on 2 p21 results from mutations disrupting either the hinge region or the conserved core structures of cytochrome P4501B1. Am J Hum Genet 629(3): 573584.

14. Alguire P (1990) The Eye Chapter 118 Tonometry Basic Science. Clinical methods: the history, physical, and laboratory examinations London.

15. Burgoyne CF, Downs JC, Bellezza AJ, Suh JK, Hart RT (2005) The optic nerve head as a biomechanical structure: a new paradigm for understanding the role of IOP-related stress and strain in the pathophysiology of glaucomatous optic nerve head damage. Prog Retin Eye Res 24(1): 39-73.

16. Mozaffarieh M, Grieshaber MC, Flammer J (2008) Oxygen and blood flow: players in the pathogenesis of glaucoma. Mol Vis 14: 224-233.

17. Harwerth RS, Wheat JL, FredetteMJ, Anderson DR (2010) Linking structure and function in glaucoma. Prog Retin Eye Res 29(4):249-271.

18. Medeiros FA, Alencar LM, Zangwill LM, Bowd C, Sample PA, et al. (2009) Prediction of functional loss in glaucoma from progressive optic disc damage. Arch Ophthalmol. 127(10): 1250- 1256.

19. Michelessi M, Lucenteforte E, Oddone F, Brazzelli M, Parravano M, et al. (2015) Optic nerve head and fibre layer imaging for diagnosing glaucoma. Cochrane Database Syst Rev 11: CD008803.

20. Wong HT, Lim MC, Sakata LM (2009) High-definition optical coherence tomography imaging of the iridocorneal angle of the eye. Arch Ophthalmol 127(3): 256-260.

21. Sakata LM, Lavanya R, Friedman DS, (2008) Comparison of gonioscopy and anterior segment ocular coherence tomography in detecting angle closure in different quadrants of the anterior chamber angle. Ophthalmology 115(5): 769-774.

22. Parikh RS, Parikh SR, Navin S, Arun E, Thomas R, et al. (2008) Practical approach to medical management of glaucoma. Indian J Ophthalmol 56(3): 223-230.

23. Boland MV, Ervin AM, Friedman DS (2013) Comparative effectiveness of treatments for open-angle glaucoma: a systematic review for the US Preventive Services Task Force. Ann Intern Med 158(4):271-279.

24. Heijl A, Leske MC, Bengtsson B, Hyman L, Bengtsson B, et al. (2002) Reduction of intraocular pressure and glaucoma progression. Arch Ophthalmol 120(10): 1268-1279.

25. Kass MA, Heuer DK, Higginbotham EJ (2002) The Ocular Hypertension Treatment Study: a randomized trial determines that topical ocular hypotensive medication delays or prevents the onset of primary openangle glaucoma. Arch Ophthalmol 120(6): 701-713.
26. American Academy of Ophthalmology Preferred Practice Patterns Committee GP. Preferred practice pattern: primary open-angle glaucoma. American Academy of Ophtalmology, Chicago, Illinois, USA.

27. Gaton DD, Sagara T, Lindsey JD, Gabelt BT, Kaufman PL, et al. (2001) Increased matrix metalloproteinases 1,2 , and 3 in the monkey uveoscleral outflow pathway after topical prostaglandin F(2 alpha)isopropyl ester treatment. Arch Ophthalmol 119(8): 1165-1170.

28. Stewart WC, Konstas AG, Nelson LA, Kruft B (2008) Meta-analysis of 24hour intraocular pressure studies evaluating the efficacy of glaucoma medicines. Ophthalmology. 115(7): 1117-1122e1.

29. Weinreb RN, Kaufman PL (2001) Glaucoma research community and FDA look to the future, II: NEI/FDA Glaucoma Clinical Trial Design and Endpoints Symposium: measures of structural change and visual function. Invest Ophthalmol Vis Sci 52(11): 7842-7851.

30. Mozaffarieh M, Flammer J (2007) Is there more to glaucoma treatment than lowering IOP? Surv Ophthalmol 52: S174-S179.

31. Liu JH, Kripke DF, Weinreb RN (2004) Comparison of the nocturnal effects of once-daily timolol and latanoprost on intraocular pressure. Am J Ophthalmol 138(3): 389-395.

32. Pardianto G (2006) Some difficulties on Glaucoma. Mimbar Ilmiah Oftalmologi Indonesia 3: 49-52.

33. Dada T, Sharma R, Sinha G, Angmo D, Temkar S (2016) Cyclodialysisenhanced trabeculectomy with triple Ologenimplantation. Eur J Ophthalmol 26(1): 95-97.

34. Cillino S, Casuccio A, Di Pace F, Cagini C, Ferraro LL, et al. (2016) Biodegradable collagen matrix implant versus mitomycinC in trabeculectomy: fiveyear followup. BMC Ophthalmol 16: 24.

35. Rulli E, Biagioli E, Riva I (2013) Efficacy and safety of trabeculectomy vs nonpenetrating surgical procedures: a systematic review and metaanalysis. JAMA Ophthalmol 131(12): 1573-1582.

36. Shingleton B, Tetz M, Korber N (2008) Circumferential viscodilation and tensioning of Schlemm's canal (canaloplasty) with temporal clear corneal phacoemulsification cataract surgery for openangle glaucoma and visually significant cataract: oneyear results. J Cataract Refract Surg 34 (3): 433-440.

37. (2012) Canaloplasty: 12 month results. Ft. Lauderdale: ARVO Congress.

38. Lewis RA (2014) Ab interno approach to the subconjunctival space using a collagen glaucoma stent. J Cataract Refract Surg 40(8): 13011306.

39. Alsagoff Z, Aung T, Ang LP, Chew PT (2000) Long-term clinical course of primary angle-closure glaucoma in an Asian population. Ophthalmology 107(12): 2300-2304.

\section{Your next submission with Juniper Publishers will reach you the below assets}

- Quality Editorial service

- Swift Peer Review

- Reprints availability

- E-prints Service

- Manuscript Podcast for convenient understanding

- Global attainment for your research

- Manuscript accessibility in different formats

( Pdf, E-pub, Full Text, Audio)

- Unceasing customer service

Track the below URL for one-step submission https://juniperpublishers.com/online-submission.php 